\title{
ANALISIS KINERJA KEUANGAN BERDASARKAN RASIO PROFITABILITAS PADA PERUSAHAAN JASA PERHOTELANYANG TERDAFTAR DI BURSA EFEK INDONESIA
}

\author{
Imelda R. Purba ${ }^{1}$, Betniar Purba ${ }^{2}$ \\ ${ }^{1,2}$ Universitas Katolik Santo Thomas Medan Jl. Setia Budi No. 479F, 20132, Indonesia \\ e-mail: imelda.rimenda.purba@gmail.com ${ }^{1}$, betniarpurba20@ gmail.com ${ }^{2}$
}

\begin{abstract}
This study aims to analyze the ability of the hotel services company in the Indonesia Stock Exchange to generate profits with the total assets available. This ability is seen from the value of ROA and the value of ROE (return on investment of shareholders). The benefit of this research is to provide information material to investors in making investment decisions. This study uses secondary data, namely the Financial Statements of Hospitality Service Companies listed on the Indonesia Stock Exchange for the period 2014-2018 which can be accessed via the internet. The data analysis technique used in this research is ratio analysis. The ratio analysis used is the profitability ratio, which is represented by Return On Assets (ROA) and Return On Equity (ROI). The results showed that in these company profitability ratios from 2014 to 2018, in general, several companies experienced a decline, which indicates that the company's profitability ratio is getting less good. Of the 5 hotel services companies studied, the authors also concluded that the Destination Company Tirta Nusantara Tbk. (PDES) is a hotel service company that has the best profitability ratio. This means that this company is a hotel service company listed on the Indonesia Stock Exchange that has the best financial performance. Meanwhile, Golden Eagle Energy Tbk. (SMMT) is a hotel service company that has the worst profitability ratio. Based on the research results, it is recommended that the management of the hotel services listed on the Indonesia Stock Exchange be able to maintain and even improve their performance from year to year. The company is also expected to be able to manage its assets properly so that the company's performance will increase and further research uses all the ratios in operational variables to assess the company's financial performance.
\end{abstract}

Keywords: Profitability Ratio, Return On Asset, and Return On Equity.

\section{PENDAHULUAN}

Media yang dapat dipakai untuk menilai kinerja keuangan adalah laporan keuangan yang mencerminkan kondisi keuangan dan hasil operasi perusahaan. Informasi tentang kondisi keuangan dan hasil operasi perusahaan sangat berguna bagi berbagai pihak, baik internal maupun eksternal perusahaan. Oleh karena itu laporan keuangan dapat dipakai sebagai alat untuk berkomunikasi dengan pihak yang berkepentingan dengan data keuangan perusahaan, dan karena ini maka sering disebut language of business.

Laporankeuangandigunakan oleh pemilik perusahaan untuk menilai sukses tidaknya manajer memimpin perusahaannya.Laporan keuangan perlu dianalisis untuk berbagai kepentingan. Dari laporan tersebut dapat diukur apakah perusahaan beroperasi efektif dan efesien serta untuk menilai kelemahan dan kekuatan perusahaan. Laporan keuangan digunakan oleh kreditor untuk mengukur kemampuan perusahaan membayar kewajibannya. Laporan keuangan digunakan oleh investor untuk mengambil keputusan apakah mereka akan menambah modal, menjual saham atau tetap menahannya. Bagi pemerintah, laporan keuangan digunakan untuk menentukan besarnya pajak yang harus ditanggung perusahaan.

Analisis laporan keuangan merupakan salah satucara untuk mengetahui kinerja keuangan perusahaan dalam satu periode tertentu (Kasmir, 2010:66). Analisislaporan keuangan adalah proses pengidentifikasian ciri-ciri keuangan perusahaan yang didapat dari data-data akutansi serta laporan keuangan lainnya.Tujuan adanya analisis laporan keuangan adalah untuk mengetahui prestasi perusahaan. Informasi posisi keuangan dimasa lalu sering kali dijadikan dasar untuk memprediksi posisi keuangan dimasa depan. Dengan melakukan analisis terhadap laporan keuangan perusahaan, manajer 


\section{Volume 20 Nomor 2, September 2020}

dapat mengetahui besarnya tingkat likuiditas, profitabilitas dan indikator lain yang menunjukkan apakah perusahaan dapat dijalankan dengan baik.

Analisis rasio adalah analisis yang bersumber dari laporan keuangan perusahaan. Melalui Analisis rasio dapat dilihat perkembangan kinerja keuangan perusahaan,perkembangan financial perusahaan dari tahun ke tahun serta dapat melakukan tindakan preventif untuk menghindari kegagalan usaha. Analisis rasio merupakan informasi keuangan yang dikonversikan dalam berbagai formula sehingga di dapat informasi yang berguna untuk mengidentifikasi kinerja perusahaan. Menurut Sofyan Syafri Harahap (2007:298) analisis rasio memiliki keunggulan disbanding teknik analisis lainnya. Adapun keunggulan tersebut adalah:

1. Rasio merupakan angka-angka atau ikhtisar statistik yang lebih mudah dibaca dan ditafsirkan;

2. Merupakan pengganti yang lebih sederhana dan informasi yang disajikan laporan keuangan yang sangat rinci dan rumit;

3. Mengetahui posisi perusahaan di tengah industry ilain;

4. Sangat bermanfaat untuk bahan dalam mengisi model-model pengambilan keputusan dan model prediksi (Z-score);

5. Menstandarisir ukuran perusahaan ;

6. Lebih mudah memperbandingkan perusahaan dengan perusahaan lain atau melihat perkembangan perusahaan secara periodic atau "time series";

7. Lebih mudah melihat trend perusahaan serta melakukan prediksi di masa yang akan datang.

Dalam penelitian ini akan dikaji kinerjakeuangan perusahaan terutama dari sisi kemampulabaan (profitabilitas). Rasio ini akan mengukur kemampuan perusahaan dalam menghasilkan keuntungan pada tingkat penjualan, aset dan modal saham. Rasio profitabilitas memberikan jawaban akhir tentang efektivitas manajemen perusahaan padasisi keuangannya (Asyikin dan Tanu, 2011). Profitabilitas suatu perusahaan akan mempengaruhi kebijakan para investor atas investasi yang dilakukan. Kemampuan perusahaan untuk menghasilkan laba akan dapat menarik para investor untuk menanamkan dananya guna memperluas usahanya, sebaliknya tingkat profitabilitas yang rendah akan menyebabkan para investor menarik dananya. Sedangkan bagi perusahaan itu sendiri profitabilitas dapat digunakan sebagai evaluasi atas efektivitas pengelolaan perusahaan tersebut.

Dalam menghitung kemampulabaan perusahaan, dapatdigunakan beberapa rasio, diantaranya:

a. Tingkat pengembalian harta (Return on Asset/ROA) yaitu laba bersih dibagitotal harta. ROA merupakan rasio pokok untuk/ mengukur tingkat keuntungan yang menunjukkan tingkat penggunaan harta.

b. Tingkat pengembalian modal (Return on Equity/ROE) yaitu laba bersih dibagi total modal yang menunjukkan tingkat kualitas modal yang digunakan.

\section{Pengertian Manajemen Keuangan}

\section{TINJAUAN PUSTAKA}

Sutrisno (2009:3) mendefinisikan manajemen keuangan sebagai :" Semua aktivitas perusahaan yang berhubungan dengan usaha-usaha mendapatkan dana perusahaan dengan dengan biaya yang murah serta usaha untuk menggunakan dana danmengalokasikan dana tersebut secara efisien". Menurut James C.Van Horne yang dikutip oleh Kasmir (2009:5), mendefinisikan manajemen keuangan adalah segala aktivitas yang berhubungan dengan perolehan, pendanaan, dan pengelolaan aktiva dengan beberapa tujuan menyeluruh.

\section{Tujuan Manajemen Keuangan}

Menurut Sutrisno (2009:4) bahwa tujuan perusahaan adalah meningkatkan kemakmuran para pemegang saham atau pemilik. Kemakmuran para pemegang saham diperlihatkan dalam wujud semakin tingginya harga saham, yang merupakan pencerminan dari keputusan-keputusan investasi, pendanaan, dan kebijakan deviden. Oleh karena itu kemakmuran para pemegang saham dapat dijadikan sebagai dasar analisis dan tindakan rasional dalam proses pembuat keputusan. Menurut Sartono (2008 : 8) tujuan manajemen keuangan adalah " memaksimumkan kemakmuran pemegang saham atau maximization wealth of stackholders melalui maksimisasi perusahaan". 


\section{Volume 20 Nomor 2, September 2020}

\section{Fungsi Manajemen Keuangan}

Tujuan manajemen keuangan tidak dapat dipisahkan dengan fungsi-fungsi lainnya di dalam perusahaan. Disini dikemukakan beberapa fungsi manajemen keuangan menurut berbagai sumber. Menurut Weston dan Brigham (2009:5) menyatakan bahwa fungsi manajemen keuangan ada empat, yaitu sebagai berikut :

a. Peramalan dan perencanaan (forecasting and planning).

b. Keputusan menyangkut investasi besar dan permodalan.

c. Pengendalian (controlling).

d. Interaksi dengan pasar modal.

Fungsi manajemen keuangan menurut Sutrisno (2009:5) terdiri dari tiga keputusan utama yang harus dilakukan oleh suatu perusahaan, yaitu :

1. Keputusan Investasi. Keputusan investasi adalah masalah bagaimana manajer keuangan harus mengalokasikan dana kedalam bentuk-bentuk investasi yang akan dapat mendatangkan keuntungan di masa yang akan datang.Keuntungan di masa depan yang diharapkan dari investasi tersebut tidak dapat diperkirakan secara pasti. Oleh karena itu, invetasi akan mengandung risiko atau ketidak pastian. Risiko dan hasil yang diharapkan dari investasi itu akan sangat mempengaruhi pencapaian tujuan, kebijakan, maupun nilai perusahaan.

2. Keputusan Pendanaan. Keputusan pendanaan ini sering disebut sebagai kebijakan struktur modal. Pada keputusan ini manajer keuangan dituntut untuk mempertimbangkan dan menganalisis kombinasi dari sumber-sumber dana yang ekonomis bagi perusahaan guna membelanjai kebutuhan-kebutuhan investasi serta kegiatan usahanya.

3. Keputusan Deviden. Deviden merupakan bagian keuntungan yang dibayarkan oleh perusahaan kepada para pemegang saham. Oleh karena itu deviden ini merupakan bagian dari penghasilan yang diharapkan oleh pemegang saham. Keputusan deviden merupakan keputusan manajemen keuangan untuk menentukan : (1) besarnya presentase laba yang dibagikan kepada pemegang saham dalam bentuk cash dividend, (2) stabilitas deviden yang dibagikan, (3) deviden saham (stock dividend), (4) pemecah saham (stock split), serta (5) penarikan kembali saham yang beredar, yang semuanya ditujukan untuk meningkatkan kemakmuran para pemegang saham.

\section{Kinerja Keuangan}

Menurut Indra Bastian (2006:317), dalam bukunya „Akuntansi Sektor Publik Di Indonesia“ menjelaskan bahwa : “ Kinerja adalah gambaran tingkat pencapaian pelaksanaan suatu kegiatan/program/kebijaksanaan dalam mewujudkan sasaran, tujuan misi dan visi organisasi yang tertuang dalam perumusan skema strategi ( strategic planning ) suatu organisasi". Jadi kinerja adalah suatu alat yang digunakan untuk mengetahui kesehatan suatu perusahaan. Dan alat utamanya untuk mengetahui sehatnya suatu perusahaan adalah laporan keuangan.

\section{Pengertian dan Tujuan Laporan Keuangan}

Kondisi keuangan suatu perusahaan akan dapat diketahui dari laporan keuangan perusahaan yang bersangkutan, oleh karena itu perlu pembahasan singkat mengenai laporan keuangan. Kasmir (2009:7) berpendapat bahwa: "Laporan keuangan adalah laporan yang menunjukkan kondisi keuangan perusahaan pada saat ini atau dalam suatu periode tertentu".

Menurut Sutrisno (2009:9) laporan keuangan merupakan hasil akhir dari proses akuntansi yang meliputi dua laporan utama, yakni (1) Neraca dan (2) LaporanLaba-Rugi.

\section{Analisis Rasio Keuangan}

Rasio keuangan merupakan angka yang diperoleh dari hasil perbandingan dari satu pos laporan keuangan dengan pos lainnya yang relevan dan signifikan. Rasio keuangan ini hanya menyederhanakan informasi yang menggambarkan hubungan antara pos tertentu dengan pos lainnya. Sehingga kita dapat membeberkan informasi dan memberikan penilaian.

Menurut Sutrisno (2009:214) dalam bukunya „, Manajemen Keuangan“ yang dimaksud Analisis Rasio Keuangan adalah menghubungkan elemen-elemen yang ada di laporan keuangan agar bisa di interpretasikan lebih lanjut. Sedangkan menurut Jumingan (2006:44) menyatakan bahwa analisis rasio 


\section{Volume 20 Nomor 2, September 2020}

keuangan merupakan alat utama dalam menganalisis keuangan, karena analisis ini dapat digunakan untuk menjawab berbagai pertanyaan tentang keadaan keuangan perusahaan.

Berdasarkan definisi di atas, dapat dikatakan bahwa rasio mengambarkan suatu hubungan dan perbandingan antara jumlah tertentu dalam satu pos laporan keuangan dengan jumlah yang lain pada pos laporan keuangan yang lain. Dengan menggunakan metode analisis seperti berupa rasio ini akan dapat menjelaskan atau memberikan gambaran tentang baik atau buruknya keadaan atau posisi keuangan suatu perusahaan. Analisis rasio keuangan juga berguna untuk menentukan kesehatan atau kinerja keuangan perusahaan baik pada saat sekarang maupun di masa mendatang.

\section{Rasio Profitabilitas}

Menurut Van Horne dan Wachowicz (2010:222), Profitabilitas merupakan rasio yang menghubungkan laba dari penjualan dan investasi. Profitabilitas mencermikan seberapa besar kemampuan perusahaan mendapatkan keuntungan. Menurut Martono dan Harjito (2005:60) Rasio profitabilitas adalah rasio yang menunjukkan efektifitas menciptakan laba. Laba pada dasarnya menunjukkan seberapa baik perusahaan dalam membuat keputusan investasi dan pembiayaan.

Dari beberapa pendapat diatas, maka dapat disimpulkan adanya kesamaan pendapat mengenai pengertian rasio profitabilitas, yaitu rasio yang dapat digunakan untuk mengukur kemampuan suatuperusahaan memperoleh laba.

Rasio profitabilitas dapat diklasifikasikan menjadi beberapa bagian, yaitu :

a. Gross Profit Margin. "Gross Profit Margin merupakan perbandingan penjualan bersih dikurangi harga pokok penjualan dengan penjualan bersih atau rasio antara laba kotor dengan penjualanbersih". (Martono dan Harjito, 2005:59). “ Rasio ini berguna untuk mengetahui keuntungan kotor perusahaan dari setiap barang yang dijual.” (Darsono dan Ashari, 2004:56).

b. Net Profit Margin. "Net profit Margin (NPM) atau Margin Laba Bersih merupakan keuntungan penjualan setelah menghitung seluruh biaya dan pajak penghasilan. Margin ini menunjukkan perbandingan laba bersih setelah pajak( EAT) dengan penjualan." (Martono dan Harjito, 2005:59). "Laba bersih dibagi dengan penjualan bersih. Rasio ini menggambarkan besarnya laba bersih yang diperoleh oleh perusahaan pada setiap penjualan yang dilakukan." (Darsono dan Ashari, 2004: 56).

c. Return on Investment (ROA). Menurut Brigham dan Houston (2009), pengembalianatas total aktiva (ROA) dihitung dengan cara membandingkan laba bersih yang tersedia untuk pemegang saham biasa dengan total aktiva.

$$
\mathrm{ROA}=\frac{\text { Laba Bersih Untuk Pemegang Saham }}{\text { Total Aktiva }}
$$

Semakin besar nilai ROA, menunjukkan kinerja perusahaan yang semakin baik pula, karena tingkat pengembalian investasi semakin besar. "Nilai ini mencerminkan pengembalian perusahaan dari seluruh aktiva (atau pendanaan) yang diberikan pada perusahaan" (Wild, Subramanyam, dan Halsey, 2010:65).

d. Return on Equity (ROE). Menurut Martono dan Harjito (2005:60) Return on Equity (ROE) atau sering disebut rentabilitas Modal Sendiri dimaksudkan untuk mengukur seberapa banyak keuntungan yang menjadi hakpemilik modal sendiri.

Return of Equity adalah ukuran kemampuan perusahaan dalam memberikan pengembalian atas investasi para pemegang saham . Return on equity menurut Van Horne dan Wachowicz (2012:226) menunjukkan daya untuk menghasilkan laba atas investasi berdasarkan nilai buku pemegang saham, dan sering kali digunakan dalam membandingkan dua atau lebih perusahaan sebuahindustri yang sama. Semakin tinggi nilai ROE menunjukkan semakin efisien perusahaan menggunakan modal sendiri untuk menghasilkan laba (Brigham, 2009).

Rumus untuk menghitung return on equity (ROE) menurut Brigham dan Houston (2009:109)

$$
\mathrm{ROE}=\frac{\text { LabaBersihUntukPemegangSaham }}{\text { ModalSendiri }}
$$




\section{METODE PENELITIAN}

\section{Ruang lingkup penelitian}

Ruang lingkup penelitian ini meliputi Analisis kinerja keuangan berdasarkan ratio profitabilitas pada perusahaan jasa perhotelan yang terdaftar di Bursa Efek Indonesia periode 2014-2018

\section{Populasi dan Sampel}

Populasi dalam penelitian ini adalah seluruh Perusahaan Jasa Perhotelan yang terdaftar di Bursa Efek Indonesia periode 2014-2018 sesuai dengan pengklasifikasian Indonesia Capital Market Directory, berjumlah 10 perusahaan.

Sampel yang digunakan dalam penelitian ini diambil dengan metode purposive sampling, yaitu pemilihan sampel berdasarkan kriteria Indriantoro dan Supomo (2002):

a. PerusahaanJasa Perhotelan yang terdaftar di Bursa Efek Indonesia sejak tahun 2014.

b. Perusahaan Jasa Perhotelan yang terdaftar di Bursa Efek Indonesia selama periode penelitian.

c. Menerbitkan laporan keuangan pada tahun 2014-2018 dan dapat diakses melalui internet. Berdasarkan kriteria tersebut, maka jumlah perusahaan yang akan dijadikan sampel adalah 5 perusahaan.

\section{OperasionalisasiVariabel}

Variabel-variabel dalam penelitian ini adalah :

1. Kinerja keuangan untuk mengetahui tingkat profitabilitas yaitu menunjukkan kemampuan perusahaan untuk mendapatkan laba selama periode tertentu dan untuk mengetahui stabilitas yaitu kemampuan perusahaan untuk melakukan usahanya dengan stabil yang diukur dengan mempertimbangkan kemampuan perusahaan membayar beban bunga atau hutangnya.

2. Rasio profitabilitas, yaitu rasio yang dapat digunakan untuk mengukur kemampuan suatu perusahaan memperoleh laba, yang diwakili oleh Return on Asset (ROA) dan Return on Equity $(R O E)$.

Return on Assets adalah ukuran kemampuan perusahaan secara keseluruhan di dalam menghasilkan keuntungan dengan jumlah keseluruhan aktiva yang tersedia di dalam perusahaan. Skala pengukurannya adalah skala rasio dalam satuan persen.

Rumus untuk menghitung Return on Assets :

$\mathrm{ROA}=\frac{\text { Laba Bersih Untuk Pemegang Săham }}{\text { Total Aktiva }}$

Return on Equity adalah ukuran kemampuan perusahaan dalam memberikan pengembalian atas investasi para pemegang saham . Skala pengukurannya adalah skala rasio dalam satuan persen

Rumus untuk menghitung Return on Equity :

$\mathrm{ROE}=\frac{\text { La ba Bersih Untuk Pemegang Saham }}{\text { Modal Sendiri }}$

\section{Tehnik Pengumpulan Data}

Dalam penelitian ini digunakan data sekunder yaitu Laporan Keuangan Perusahaan Jasa Perhotelan yang terdaftar di Bursa Efek Indonesia periode 2014-2018 yang dapat diakses melalui internetdari website www.idx.co.id.

\section{Tehnik Analisis Data}

Teknik analisis data yang digunakan dalam penelitian iniadalah Analisis Rasio. Analisis Rasio yang digunakan adalah Rasio Profitabilitas yang diwakilkan oleh Return on Asset (ROA)dan Return on Equity (ROE). Return on Assets adalah ukuran kemampuan perusahaan secara keseluruhan di dalam menghasilkan keuntungan dengan jumlah keseluruhan aktiva yang tersedia di dalam perusahaan. Dengan mengetahui ROA, kita dapat menilai apakah perusahaan telah efisien dalam menggunakan aktivanya dalam kegiatan operasi untuk menghasilkan keuntungan. Rumus untuk menghitung return on assets menurut Brigham dan Houston (2009:109)

$$
\mathrm{ROA}=\frac{\text { Laba Bersih untuk Pemegang Saham }}{\text { Total Aktiva }}
$$




\section{Volume 20 Nomor 2, September 2020}

Return on Equity adalah ukuran kemampuan perusahaan dalam memberikan pengembalian atas investasi para pemegang saham . Semakin tinggi nilai ROEmenunjukkan semakin efisien perusahaan menggunakan modal sendiri untuk menghasilkan laba (Brigham, 2009). Rumus untuk menghitung Return on Equity (ROE) menurut Brigham dan Houston (2009:109)

$$
\mathrm{ROE}=\frac{\text { Laba Bersih untuk Pemegang Saham }}{\text { Modal Sendiri }}
$$

\section{HASIL PENELITIAN DAN PEMBAHASAN}

Perusahaan-perusahan go public yang tercatatpada PT Bursa Efek Indonesia diklasifikasikan menurut sektor industri yang telah ditetapkan ole PT Bursa Efek Indonesia yang disebut dengan JASICA (Jakarta Stock Exchange Industry Classification). Terdapat 9 (sembilan) sektor industry berdasarkan klasifikasi PT Bursa Efek Indonesia.

Data yang digunakan dalam penelitian ini adalah data sekunder. Data sekunder adalah data yang dikumpulkan dari sumber-sumber cetak, dimana data itu telah dikumpulkan oleh pihak lain sebelumnya. Populasi yang digunakan dalam penelitian ini adalah perusahaan Jasa Perhotelan yang terdaftar di Bursa Efek Indonesia. Bursa Efek Indonesia merupakan penggabungan antara Bursa Efek Jakarta (BEJ) dan Bursa Efek Surabaya (BES) yang berganti nama menjadi Bursa Efek Indonesia ( BEI) pada tanggal 30 November 2007. Setelah dilakukan pemilihan sampel dengan metode purposive sampling diperoleh sampel penelitian berjumlah 5 perusahaan.

Return On Asset (ROA) merupakan salah satu rasio profitabilitas, yaitu rasio yang menunjukkan seberapa efektifnya perusahaan beroperasi sehingga menghasilkan keuntungan atau laba perusahaan. Return on asset (ROA) juga merupakan salah satu rasio yang mengukur tingkat profitabilitas suatu perusahaan. Return on asset (ROA) digunakan untuk mengetahui besarnya laba bersih yang dapat diperoleh dari operasional perusahaan dengan menggunakan seluruh kekayaannya. Tinggi rendahnya Return On Asset (ROA) tergantung pada pengelolaan asset perusahaan oleh manajemen yang menggambarkan efisiensi dari operasional perusahaaan. Semakin tinggi Return On Asset (ROA) semakin efisien operasional perusahaan dan sebaliknya, rendahnya Return On Asset (ROA) dapat disebabkan oleh banyaknya asset perusahaan yang menganggur, investasi dalam persediaan yang terlalu banyak.

Tabel 1. Return On Asset Perusahaan Jasa Perhotelan yang Terdaftar di Bursa Efek Indonesia Tahun 2014-2018

\begin{tabular}{|c|l|l|l|l|l|l|l|}
\hline \multirow{2}{*}{ No } & \multicolumn{2}{|c|}{ Nama Perusahaan } & \multirow{2}{*}{ Kode } & \multicolumn{5}{|c|}{ Return On Asset (\%) } \\
\cline { 4 - 8 } & & & 2014 & 2015 & 2016 & 2017 & 2018 \\
\hline 1 & Bayu Buana Tbk. & BAYU & 0.20 & 3.42 & 4.75 & 4.77 & 3.34 \\
\hline 2 & Fast Food Indonesia Tbk. & FAST & 17,48 & 16,15 & 14,80 & 11,56 & 5,69 \\
\hline 3 & Grahamas Citrawisata Tbk. & GMCW & 11,64 & 12.82 & 17,87 & 13,95 & $-9,64$ \\
\hline 4 & Destinasi Tirta Nusantara Tbk. & PDES & 1,76 & 1.72 & 3,23 & 3,98 & 6,97 \\
\hline 5 & Golden Eagle Energy Tbk. & SMMT & $-20,34$ & $-17,70$ & 2,98 & 3,09 & 0,94 \\
\hline
\end{tabular}

Sumber: Ikhtisar Keuangan Perusahaan (diolah)

Tabel 1.menunjukkan nilai Return On Asset (ROA) untuk tahun 2014, 2015, 2016, 2017 dan 2018. Nilai ROA tertinggi untuk tahun 2014 dan 2015 adalah perusahaan FAST, yaitu sebesar 17,48\% dan 16,15\%; pada tahun 2016 dan 2017 nilai ROA tertinggi adalah perusahaan GMCW, yaitu sebsar 17,87\% dan 13,95\%; dan pada tahun 2018 adalah perusahaan PDES sebesar 6,97\%. Sedangkan nilai ROA yang paling rendah setiap tahun adalah perusahaan SMMT yang mengalami ROA negatif selama dua tahun berturut-turut pada 2014 dan 2015, yaitu sebesar $-20,34 \%$ dan $-17,70 \%$. Pada tahun 2016 dan 2017, ROA SMMT mengalami kenaikan, yaitu $2.98 \%$ dan $3.09 \%$ dan kembali mengalami penurunan menjadi $0.94 \%$ di tahun 2018

Return on Equity (ROE) atau pengembalian atas ekuitas mengukur pengembalian atas pemegang saham biasa; rasio ini juga dikalkulasi sebagai pengembalian atas ekuitas saham biasa jikalau sebuah perusahaan memiliki saham preferen yang beredar. Angka ROE yang semakin tinggi memberi indikasi bagi pemegang saham bahwa tingkat pengembalian investasi makin tinggi. 
Tabel 2. Return On Equity Perusahaan Jasa Perhotelan yang Terdaftar di Bursa Efek Indonesia Periode 2014-2018

\begin{tabular}{|l|l|l|l|l|l|l|l|}
\hline \multirow{2}{*}{ No } & \multirow{2}{*}{ Nama Perusahaan } & \multirow{2}{*}{ Kode } & \multicolumn{5}{|c|}{ Return On Equity (\%) } \\
\cline { 4 - 8 } & & & 2014 & 2015 & 2016 & 2017 & 2018 \\
\hline 1 & Bayu Buana Tbk. & BAYU & 0.46 & 7.66 & 10.42 & 10.04 & 6.84 \\
\hline 2 & Fast Food Indonesia Tbk. & FAST & 28.48 & 24.90 & 27.57 & 20.80 & 10.22 \\
\hline 3 & Grahamas Citrawisata Tbk. & GMCW & 30.12 & 23.29 & 32.21 & 21.23 & -14.90 \\
\hline 4 & Destinasi Tirta Nusantara Tbk. & PDES & 2.80 & 3.20 & 6.19 & 6.66 & 12.47 \\
\hline 5 & Golden Eagle Energy Tbk. & SMMT & $-30,94$ & 24,26 & 8,86 & 3,21 & 4,17 \\
\hline
\end{tabular}

Sumber: Ikhtisar Keuangan Perusahaan (diolah)

Dari tabel diatas dapat dilihat bahwa nilai ROE yang paling tinggi pada tahun 2014 adalah GMCW, yaitu sebesar 30.12\%; tahun 2015 adalah FAST, yaitu sebesar 24.90\%; tahun 2016 dan 2017 adalah GMCW, yaitu sebesar 32.21\% dan 21.23\%; dan tahun 2018 adalah FAST, yaitu sebesar $10.22 \%$. Sedangkan ROE yang paling rendah pada tahun 2014 adalah BAYU, yaitu sebesar $0.46 \%$; pada tahun 2015 adalah PDES, yaitu sebesar 3.20\%; tahun 2016 dan 2017 adalah SMMT, yaitu sebesar -30,94\% dan 3,21\%; tahun 2018 adalah GMCW, yaitu sebesar $-14.90 \%$.

\section{PEMBAHASAN}

Rasio profitabilitas memberikan gambaran tentang kinerja suatu perusahaan selama periode tertentu. Dalam hal ini, perusahaan menyusun laporan keuangan yang dibutuhkan oleh berbagai pihak yang berkepentingan terhadap perusahaan tersebut. Pihak-pihak yang berkepentingan terhadap laporan keuangan,yaitu seperti investor, kreditor, pimpinan perusahaan, karyawan dan pemerintah. Dari analisis rasio profitabilitas akan dapat diketahui hasil-hasil yang telah dicapai perusahaan pada masa lalu sebagai bahan pertimbangan dalam penerapan rencana serta kebijaksanaan perusahaan pada waktu yang akan datang. Salah satu teknik penilaian kinerja adalah dengan menggunakan analisis rasio profitabilitas.

Profitabilitas adalah hasil bersih dari serangkaian kebijakan dan keputusan, rasio ini menunjukkan pengaruh gabungan dari likuiditas, pengelolaan utang terhadap hasil-hasil operasi. Rasio profitabilitas mengukur seberapa besar kemampuan perusahaan dalam menghasilkan keuntungan.

Tabel 3.Return On Asset dan Penilaiannya

\begin{tabular}{|l|l|l|l|l|l|l|l|}
\hline \multirow{2}{*}{ No } & \multirow{2}{*}{ Nama Perusahaan } & \multicolumn{5}{|c|}{ ROA (\%) } & \multirow{2}{*}{ Penilaian } \\
\cline { 3 - 7 } & & 2014 & 2015 & 2016 & 2017 & 2018 & \\
\hline 1 & BAYU & 0,20 & 3,42 & 4,75 & 4,77 & 3,34 & Bagus \\
\hline 2 & FAST & 17,48 & 16.15 & 14,80 & 11,56 & 5,69 & Kurang \\
\hline 3 & GMCW & 11,64 & 12,82 & 17,87 & 13,95 & $-9,64$ & Kurang \\
\hline 4 & PDES & 1,76 & 1,72 & 3,23 & 3,98 & 6,97 & Bagus \\
\hline 5 & SMMT & 16,04 & $-20,34$ & $-17,70$ & 2,98 & 3,09 & Kurang \\
\hline
\end{tabular}

Sumber: Diolah oleh Penulis

Return On Asset perusahaan yang terus mengalami penurunan dari tahun ke tahun yaitu FAST

Tahun 2014. Tingkat pengembalian aset sebesar 17.48\% mencerminkan bahwa setiap Rp 1,00 total aktiva mampu menghasilkan laba bersih sebesar Rp 17,48. Penulis menilai kinerja perusahaan dengan rasio ini cukup baik, dimana kinerja aktiva jika dibandingkan dengan perusahaan sejenisnya merupakan yang paling tinggi.

Tahun 2015. Tingkat pengembalian aset sebesar 16,15\% mencerminkan bahwa setiap Rp 1.00 total aktiva mampu menghasilkan laba bersih sebesar Rp 16,15. Jika dibandingkan dengan tingkat pengembalian aset untuk perusahaan sejenisnya, rasio ini sebenarnya sudah cukup baik, namun jika dilakukan perbandingan secara periodik, rasio ini mengalami penurunan dari tahun sebelumnya sebesar $1,33 \%$. 


\section{Volume 20 Nomor 2, September 2020}

Tahun 2016. Tingkat pengembalian aset sebesar 14,80\% mencerminkan bahwa setiap Rp 1,00 total aktiva mampu menghasilkan laba bersih sebesar Rp 14,8. Dibandingkan dengan tahun 2015 terjadi penurunan sebesar $1,35 \%$.

Tahun 2017. Tingkat pengembalian aset sebesar 11,56\% mencerminkan bahwa setiap Rp 1 total aktiva mampu menghasilkan laba bersih sebesar Rp 11,56. Dibandingkan dengan tahun 2016 terjadi penurunan sebesar 3,24\%.

Tahun 2018. Tingkat pengembalian aset sebesar 5,69\% mencerminkan bahwa setiap Rp 1 total aktiva mampu menghasilkan laba bersih sebesar Rp 5,69. Dibandingkan dengan tahun 2017 terjadi penurunan sebesar 5,87\%.

Return On Asset perusahaan yang terus mengalami kenaikan dari tahun ke tahun yaitu perusahaan PDES

Tahun 2014. Tingkat pengembalian aset sebesar 1,76\% mencerminkan bahwa setiap Rp 1,00 total aktiva mampu menghasilkan laba bersih $\mathrm{Rp}$ 1,76. Penulis menilai kinerja perusahaan terhadap rasio ini kurang baik. Kinerja aktiva terlihat masih belum optimal karena kurang efektif untuk menghasilkan laba bersih demi meningkatkan pendapatan.

Tahun 2015. Tingkat pengembalian aset sebesar 1,72\% mencerminkan bahwa setiap Rp 1,00 total aktiva mampu menghasilkan laba bersih Rp 1,72. Dibandingkan dengan tahun 2014 terjadi penurunan sebesar $0,04 \%$.

Tahun 2016. Tingkat pengembalian aset sebesar 3,23\% mencerminkan bahwa setiap Rp 1,00 total aktiva mampu menghasilkan laba bersih Rp 3,23. Dibandingkan dengan tahun 2015 terjadi kenaikan sebesar $1,51 \%$.

Tahun 2017. Tingkat pengembalian aset sebesar 3,98\% mencerminkan bahwa setiap Rp 1,00 total aktiva mampu menghasilkan laba bersih Rp 3,98. Dibandingkan dengan tahun 2016 terjadi kenaikan sebesar $0,75 \%$.

Tahun 2018. Tingkat pengembalian aset sebesar 6,97\% mencerminkan bahwa setiap Rp 1,00 total aktiva mampu menghasilkan laba bersih Rp 6,97. Dibandingkan dengan tahun 2017 terjadi kenaikan sebesar $2,99 \%$.

Tabel 4.Return On Equity dan Penilaiannya

\begin{tabular}{|l|l|l|l|l|l|l|l|}
\hline \multirow{2}{*}{ No } & \multirow{2}{*}{ Nama Perusahaan } & \multicolumn{5}{|c|}{ Return On Equity (\%) } & \multirow{2}{*}{ Penilaiaan } \\
\cline { 3 - 8 } & & 2014 & 2015 & 2016 & 2017 & 2018 & \\
\hline 1 & BAYU & 0.46 & 7.66 & 10.42 & 10.04 & 6.84 & Bagus \\
\hline 2 & FAST & 28.48 & 24.90 & 27.57 & 20.80 & 10.22 & Kurang \\
\hline 3 & GMCW & 30.12 & 23.29 & 32.21 & 21.23 & $-14,90$ & Kurang \\
\hline 4 & PDES & 2.80 & 3.20 & 6.19 & 6.66 & 12,47 & Bagus \\
\hline 5 & SMMT & $-30,94$ & 24,26 & 8,86 & 3,21 & 4,17 & Kurang \\
\hline
\end{tabular}

Sumber: Diolah Penulis

Return On Equity perusahaan yang mengalami penurunan dari tahun ke tahun yaitu SMMT

Tahun 2014. Rasio modal sendiri sebesar -30,94\% mencerminkan bahwa setiap Rp 100 modal sendiri dapat menghasilkan laba bersih Rp 30,94. Namun rasio modal sendiri tahun 20014 menunjukkan tanda negatif yang disebabkan oleh total ekuitas perusahaan juga negatif akibat laba ditahan perusahaan mengalami penurunan. Penulis menilai kinerja perusahaan terhadap rasio ini kurang baik, dimana kinerja modal sendiri tidak mampu menghasilkan laba bersih pada perusahaan untuk meningkatkan pendapatan.

Tahun 2015. Rasio modal sendiri sebesar 24,26\% mencerminkan bahwa setiap Rp 100 modal sendiri menghasilkan laba bersih Rp 24,26. Dibandingkan dengan tahun 2014, rasio modal sendiri mengalami peningkatan sebesar $6,68 \%$.

Tahun 2016. Rasio modal sendiri sebesar 8,86\% mencerminkan bahwa setiap Rp 100 modal sendiri menghasilkan laba bersih Rp 8,86. Dibandingkan dengan tahun 2015, rasio modal sendiri mengalami penurunan sebesar $14,7 \%$. Hal ini disebabkan karena penurunan laba bersih yang diikuti dengan peningkatan ekuitas perusahaan.

Tahun 2017. Rasio modal sendiri sebesar 3,21\% mencerminkan bahwa setiap Rp 100 modal sendiri mampu menghasilkan laba bersih Rp3,21. Dibandingkan dengan tahun 2016, rasio modal sendiri mengalami penurunan sebesar 5,65\%. Hal ini disebabkan karena kenaikan laba bersih. 


\section{Volume 20 Nomor 2, September 2020}

Tahun 2018. Rasio modal sendiri sebesar 4,17\% mencerminkan bahwa setiap Rp 100 modal sendiri menghasilkan laba bersih Rp 4,17. Dibandingkan dengan tahun 2017, rasio modal sendiri mengalami peningkatan sebesar $0,96 \%$ disebabkan karena peningkatan laba bersih.

Return On Equity perusahaan yang terus mengalami kenaikan dari tahun ke tahun yaitu Perusahaan PDES.

Tahun 2014. Rasio modal sendiri sebesar 2,80\% mencerminkan bahwa setiap Rp 100 modal sendiri menghasilkan laba bersih $\mathrm{Rp} 2,80$. Penulis menilai kinerja perusahaan terhadap rasio ini kurang baik, karena kinerja modal sendiri belum optimal karena kurang efektif untuk menghasilkan laba bersih pada perusahaan untuk meningkatkan pendapatan.

Tahun 2015. Rasio modal sendiri sebesar 3,20\% mencerminkan bahwa setiap Rp 100 modal sendiri menghasilkan laba bersih Rp 3,20. Dibandingkan dengan tahun 2014 mengalami kenaikan sebesar $0,4 \%$ karena kenaikan laba bersih.

Tahun 2016. Rasio modal sendiri sebesar 6,19\% mencerminkan bahwa setiap Rp 100 modal sendiri menghasilkan laba bersih Rp 6,19. Dibandingkan dengan tahun 2015 mengalami kenaikan sebesar 2,99\% karena kenaikan laba bersih.

Tahun 2017. Rasio modal sendiri sebesar $6,66 \%$ mencerminkan bahwa setiap Rp 100 modal sendiri menghasilkan laba bersih Rp 6,66. Dibandingkan dengan tahun 2016 mengalami kenaikan sebesar $0,47 \%$ karena kenaikan laba bersih.

Tahun 2018. Rasio modal sendiri sebesar 12,47\% mencerminkan bahwa setiap Rp 100 modal sendiri menghasilkan laba bersih Rp 12,47. Dibandingkan dengan tahun 2017 mengalami kenaikan sebesar 5,81\% karena kenaikan laba bersih.

\section{KESIMPULAN}

Perubahan kinerja keuangan Perusahaan Jasa Perhotelan yang dilihat berdasarkan rasio profitabilitas perusahaan dari tahun 2014 sampai dengan tahun 2018, yaitu : Return On Asset (ROA) dan Return On Equity (ROE). Dalam perkembangannya, rasio-rasio profitabilitas perusahaan ini mulai dari tahun 2014 sampai dengan tahun 2018 pada umumnya berfluktuasi dan beberapa perusahaan mengalami rasio yang negatif dimana hal ini menandakan semakin kurang baiknya kinerja rasio profitablitas perusahaan.

Dari 5 Perusahaan Jasa Perhotelan yang diteliti, Penulisjuga menyimpulkan bahwa Perusahaan PDES merupakan Perusahaan Jasa Perhotelan yang memiliki kinerja rasio profitabilitas yang paling baik. Artinya perusahaan ini merupakan Perusahaan Jasa perhotelan yang terdaftar di Bursa Efek Indonesia yang memiliki kinerja yang paling baik. Sedangkan Perusahaan SMMT merupakan Perusahaan Jasa Perhotelan yang memiliki rasio profitabilitas yang paling buruk.

\section{DAFTAR PUSTAKA}

Asyikin, Jumirin dan Veronica Suyanti Tanu, 2011. Analisis Perbandingan Kinerja Keuangan Perusahaan Farmasi Milik Pemerintah dan Milik Swasta yang Terdaftar pada Bursa Efek Jakarta, Jurnal SPREAD, April 2011, Volume 1 no. 1.

Baridwan, Zaki, 2004. Accounting Intermediate. Edisi Kedelapan, Cetakan Pertama, Universitas Gajah Mada, Yokyakarta: Penerbit BPFE.

Bastian, Indra, 2006. Akuntansi Pendidikan, Jakarta: Penerbit Liberty.

Bringham, Eugene F, Joel F. Houston, 2009.Dasar-Dasar Managemen Keuangan, Edisi 10Buku 1, Jakarta: Salemba Empat.

Darsono dan Ashari, 2004.Pedoman Praktis Memahami Laporan Keuangan, Yokyakarta: Andi Offset. Harahap, SofyanSyafri, 2006. Analisis Kritis Atas Laporan keuangan, Jakarta : Raja Grafindo Persada. Jumingan, 2006. Analisis Laporan Keuangan, Cetakan Pertama, Jakarta: PT. Bumi Aksara.

Kasmir, 2009, Pengantar Manajemen Keuangan, Jakarta: Kencana Prenada Group.

Kusumadiyanto, Andra, 2006. Analisis Laporan Keuangan Untuk Menilai Kinerja Perusahaan Pada KelompokIndustriRokok (Studi Survei Pada Kelompok Industri Rokok di Bursa Efek Jakarta), Skripsi, FE UniversitasWidyatama. 
Mahsun, Mohammad, 2006. Pengukuran Kinerja Sektor Publik, Edisi Pertama, Yokyakarta: Penerbit BPFE.

Martono dan D. AgusHarjito, 2005. Manajemen Keuangan Perusahaan, Edisi Pertama, Cetakan Kelima, Yokyakarta: Ekonisia.

Munawir, S. 2007. Analisa Laporan Keuangan, EdisiKetiga, Yogyakarta :Penerbit Liberty.

Muschlich, Mohammad. 2003. Manajemen Keuangan Modern, Analisis, Perencanaan dan Kebijaksanaan, Cetakan Ketiga, Universitas Indonesia, Jakarta: Bumi Aksara dan Pusat Antar Universitas Studi Ekonomi.

Sartono, R. Agus. 2008. ManajemenKeuangan, EdisiKeempat, Yogyakarta: BPFE-UGM.

Sawir, Agnes. 2003. Analisis Kinerja Keuangan dan Perencanaan Keuangan Perusahaan, Jakarta: Penerbit PT. Gramedia Pustaka Utama.

Subramankam, Kr, John J Wild, 2010. Analisis Laporan Keuangan, Jakarta: Salemba Empat.

Sutrisno. 2009. Manajemen Keuangan Teori, Konsep dan aplikasi, Edisi Pertama, Cetakan Ketujuh, Yokyakarta: Penerbit Ekonisia Kampus Fakultas Ekonomi.

Van horne, James C dan Jhon Martin Wachowicz, Fundamental of Financial Management, http://books.google.com/about/Fundamental_of_Financial_managemetn.html, diunduh pada 25 April 2012 pukul 21.45 WIB.

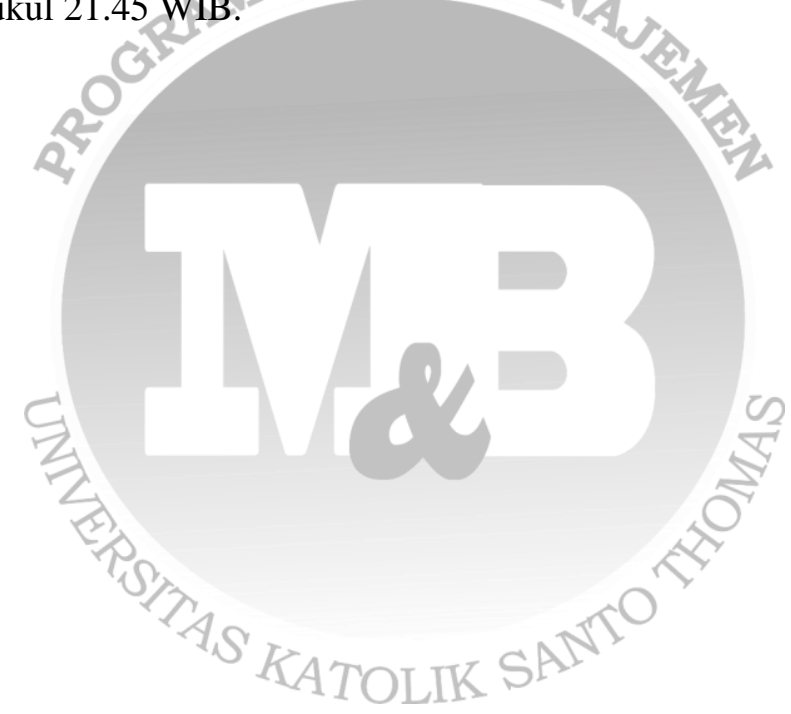

